\title{
Introduction to "Why Unions in the United States will Die: American Labor Organizations in the Age of Trump"
}

\author{
Victor G. Devinatz ${ }^{1}$
}

Published online: 16 March 2017

(C) Springer Science+Business Media New York 2017

Donald Trump's election as US president in November 2016 was surprising given that virtually all pollsters had predicted that Hillary Clinton would win the Electoral College by a comfortable margin. In addition to capturing the battleground states of Ohio, Florida and North Carolina, Trump also emerged victorious in the "Rust Belt" states of Pennsylvania, Michigan and Wisconsin by the slim margin of a total of 104,000 votes. With the loss of these latter three states which pollsters had considered to be comfortably in the Democratic Party column, there was no way for Clinton to achieve victory in the Electoral College despite her winning the popular vote by a margin of 2.9 million ballots. Although the US trade unions have historically backed the Democratic Party since Franklin Delano Roosevelt's reelection in 1936, the 2016 election was significant in that it was the first time in which many union members did not support their leaders' chosen candidate for the US presidency. While Trump's campaign contained numerous racist, sexist and misogynistic appeals to his voter base, what may have resonated most deeply with white workers was his anti-free trade rhetoric and his promise to bring back hundreds of thousands of manufacturing jobs to the industriallydevastated states of Ohio, Pennsylvania, and Michigan which have experienced countless factory closings in auto, steel and related industries over the past three decades. Because of globalization and automation, Trump is unlikely to restore a significant number of US manufacturing jobs to this industrial heartland. Moreover, a Trump presidency may be disastrous for the fortunes of US labor. Although the US trade unions have been struggling in recent decades as indicated by declining union density and decreased bargaining power, during the last eight years of President Obama's administration, labor organizations have received some minimal benefits from his policies.

In this timely, well-written and interesting "Perspectives" Section article, Dr. Raymond Hogler, Professor of Management at Colorado State University and former Distinguished Chair in Labor Law at the University of Tuscia (Viterbo, Italy), analyzes what Donald Trump's election to the US presidency will potentially mean for the US labor movement as well as for

Victor G. Devinatz

vgdevin@ilstu.edu

1 Department of Management \& Quantitative Methods, Illinois State University, Normal, IL 61790-5580, USA 
the white middle-aged male voters lacking college degrees who were a base of support for his victory and who also comprise the foundation of US trade unions. Hogler argues that culture, rather than economics, is the key component in understanding how Trump won the major industrial states. And while Trump's populist economic rhetoric appears to indicate sympathy for US working-class concerns, Hogler discusses why Trump's policies will likely lead to further difficulty for the US working class as measured by decreased levels of union density and higher rates of economic inequality.

If any of the journal's readers are interested in responding to any essays published in the "Perspectives" Section or would like to write articles on any topics in the field of employee relations, please do not hesitate to contact me with your proposal. I welcome both practitionerbased and scholarly-based articles written from any one of a variety of theoretical perspectives. I hope that you enjoy this article and find it most illuminating. 